\title{
Lembranzas dun bo profesor
}

\author{
JUAN CONESA ARIAS \\ Universidad Nacional de Educación a Distancia \\ jconesa59@alumno.uned.es
}

Os alumnos que tiña daquela chamabámoslle Don Manuel. Lembro que aínda eramos poucos os alumnos que, morando fóra de Galicia, escolleramos un dos tres cursos de «Lingua e Literatura Galegas». Porque, na altura, eran tres materias anuais e estudabamos lingua galega e mais a súa literatura. Aquela foi unha das maiores aventuras intelectuais da miña vida.

Aínda o lembro no seu escritorio no Edificio de Humanidades da UNED. Alí estiven máis dunha vez, xunto cunha compañeira, a deixar o tempo pasar mentres estabamos a escoitalo falar de literatura. Porque estou certo de que a súa paixón por riba da lingua era a literatura. Explicábaa coma se fose un conto. Un conto en que dúas persoas xa maiores (que non eramos tan novos, non, que xa tiñamos unha idade daquela) quedaban envoltas até que terminaba. E decorrían dúas ou tres horas, moitas veces sen nos darmos conta do paso do tempo. Esa era a súa maxia, a súa arte...

Eu quería aprender o galego por dúas razóns. A familia da miña muller é galega e moitos teñen coma lingua materna o galego e non o castelán. E tamén porque os meus bisavós eran galegos. Para min era como facerlles unha homenaxe. Aínda lembro a primeira redacción que lle enviei. Porque daquela non tiñamos profesor tutor, non... El era a Equipa Docente e mais o profesor tutor. Por tanto, corrixía os nosos exercicios, as nosas primeiras loitas cunha lingua que, aínda que coñecida, nos era case allea. E falando con D. Manuel polo teléfono (daquela tampouco había a Internet) fun aprendendo a falar o galego normativo, non o galego que eu ouvía falar en Vigo, onde vivían os parentes da miña muller. E tamén, nesas sesións de parolada verbo de literatura descubrín a Rosalía de Castro. A gran Rosalía de Castro, que sospeito que para D. Manuel tamén era a súa poeta preferida (probabelmente xunto co seu paisano Celso Emilio Ferreiro). E inculcoume a súa paixón pola gran Rosalía. Aínda lembro a súa explicación do poema «Unha vez tiven un cravo»...

Son tantas cousas que ven á miña memoria cando o lembro... Eu tiña tamén unha teoría sobre a orixe do castelán, máis próxima do galego ca do vasco, se cadra por contrariar a Menéndez Pidal e compaña... E isto foi o derradeiro que eu fixen xunta el. Coido que non haberá moitas persoas de fala non galega que leran a «Crónica Troiana», da que aínda conservo o exemplar. E lina porque mo 
suxeriu don Manuel. Porque ese era o camiño para comezar a ver o galego máis antigo e, por tanto, máis próximo do castelán antigo.

Despois diso, os nosos camiños afastáronse... Hoxe só me queda a lembranza. A lembranza dun querido profesor. Do profesor que un sempre gusta de ter. Unha persoa namorada do que fai e que transmite ese amor. Ese era D. Manuel. E de certo que, alá onde estiver, continuará a transmitir o seu amor pola doce lingua galega e a súa fermosa literatura.

Sit Tibi Terra Levis, Amice. 